\title{
РОЛЬ МЕДИЧНОЇ СЕСТРИ В РЕАБІЛІТАЦІЇ ХВОРИХ НА ОСТЕОХОНДРОЗ XPEБTA
}

\author{
Д. В. Бобильов, А. О. Голяченко \\ Харківський базовий медичний коледж № 1 \\ ДВНЗ «Тернопільський державний медичний університет \\ імені І. Я. Горбачевського МОЗ України"
}

У статті проаналізовано роль медичної сестри на різних етапах реабілітації хворих на остеохонд-
роз хребта.

\section{ROLE OF NURSES IN THE REHABILITATION OF PATIENTS WITH SPINAL} OSTEOCHONDROSIS

\author{
D. V. Bobylov, A. O. Holyachenko \\ Kharkiv Basic Medical College № 1 \\ SHEI «Ternopil State Medical University by I. Ya. Horbachevsky of MPH of Ukraine»
}

The article analyzes the role of nurses in various stages of rehabilitation of patients with spinal osteochondrosis.

Вступ. В останні роки проблема захворювань хребта набуває все більшо гостроти. Поширеність ціє патологі, висока частота тимчасово та стійко втрати працездатності зумовлюють соціальну значущість проблеми. В Укра ні вертеброгенна патологія в загальній структурі захворюваності з тимчасовою втратою працездатності посідає друге місце, поступаючись респіраторним інфекціям. Частота первинного встановлення інвалідності хворим з вертеброгенною патологією становить 71-74 \%, тобто 15-17 \% від усіх хворих, яким MCEК встановлює інвалідність [1].

За свідченнями науковців (O. Scherak, Т. Полякова, Я. Попелянський та інші), хвороби хребта посідають одне з перших місць за поширеністю серед населення земно кулі.

Як стверджують дослідники Н. Косинская, А. Осна, I. Тагер, В. Дяченко, Г. Юмашев, С. Arseni, M. Simonescu, W. Bosnew, L. Hirsh, V. Putti, F. Reischauer, остеохондроз хребта $\epsilon$ найбільш поширеною патологією опорно-рухового апарату людини.

Н. Яхно зауважує, що в Росі близько $80 \%$ осіб у популяці протягом життя переносять на-

(ㄷ. Д. В. Бобильов, А. О. Голяченко, 2015 пади поперекового болю; В. Матов констатує, що в розвинутих кра нах світу остеохондроз хребта складає 90 \% від загально кількості дистрофічних захворювань хребта. У Швеці, при населенні в 8,4 млн осіб, щорічно інвалідами на грунті остеохондрозу хребта стають 13 тис. осіб.

Основна частина. Практична діяльність медичних сестер пов'язана з необхідністю прийняття ними відповідальних рішень в умовах підвищеного напруження, ризику, дефіциту часу й інформаці. Зокрема, вони змушені регулярно розв'язувати різнопланові проблемні ситуаці, які виникають в хній професійній діяльності, що не мають однозначно правильних рішень, однак, х наслідки для пацієнта можуть бути дуже серйозними [2].

Саме до таких професійних ситуацій, враховуючи $\mathrm{x}$ поширеність, належать ті, що пов'язані 3 доглядом та реабілітацією хворих на остеохондроз хребта.

3 метою реалізаці поставлено задачі важливо забезпечити цілеспрямоване формування у медичних сестер умінь адекватно реагувати на проблемні ситуаці під час виконання професійних обов'язків, визначати різні варіанти х розв'язання, самостійно обирати оптимальніші, проявляти неординарність й оригі- 
нальність мислення в процесі прийняття рішень. У світлі вищезазначеного, існує необхідність у забезпеченні якісно підготовки майбутніх медичних сестер до виконання ролі ефективного члена медико-соціально бригади при реабілітаці хворих на остеохондроз хребта.

За даними наукових досліджень А. Євсюкова, І. Антонова, А. Бєлова, В. Єпіфанова питома вага клінічних проявів, пов'язаних із патологією хребта, серед всіх захворювань периферійно нервово системи становить 67-95\% [3].

О. Скоромець звертає увагу не тільки на велику частоту захворювань хребта та відсутність тенденці до х зменшення, а й на те, що вони уражають людей працездатного віку та призводять до значних втрат медичного та економічного характеру. Це зумовлює актуальність розробки та впровадження ефективних методик відновного лікування хворих із даною патологією.

Г. Юмашев, В. Єпіфанов та інші підкреслюють, що різноманітність клінічних форм вертеброгенних захворювань зумовлює різноманіття способів відновлення. Науковці наголошують, що воно повинне бути комплексним, диференційованим, з урахуванням особливостей клінічних форм ураження, індивідуальних реакцій систем організму хворих на окремі методи.

Г. Нєдзьвєдь засвідчує, що фізичні вправи вже на ранніх стадіях розвитку медицини використовувалися в профілактичних цілях та для лікування різних захворювань і сьогодні, будучи одним 3 ефективних засобів підвищення захисно-компенсаторних реакцій організму, широко використовуються в фізичній реабілітаці хворих із різними захворюваннями, у тому числі при патологі хребта.

О. Лазарєва, І. Жарова, В. Фіщенко, І. Рой звертають увагу на актуальність розробки оптимальних програм фізично реабілітаці при патологі хребта з використанням сучасних методів фізичних впливів, визначення термінів застосування найбільш раціональних режимів.

Р. Геллі, В. Єпіфановим, І. Кульченко та іншими запропоновано використання різних засобів і методів реабілітаці для лікування й профілактики патологі опорно-рухового апарату [4].

Проте слід зазначити, що у проаналізованих наукових джерелах не розкрито роль медично сестри у реабілітаційному процесі. Саме тому ми звернулися до психолого-педагогічних публікацій з питань реформування медсестринсько освіти в Укра ні. Шляхи удосконалення навчально діяльності студентів у вищих медичних навчальних закладах досліджували Л. Артемчук, О. Біловол, О. Волосовець, Л. Джулай, Т. Кудрявцева, Є. Мілерян, М. Шегедин та інші.
Проблеми медично освіти в Укра ні та закордоном розкрито у дослідженнях І. Булах, Ю. Лавриш, Г. Паласюк, В. Передерія, Ю. Поляченка, Я. Цехмістера та інших.

Незважаючи на очевидну актуальність та науково-практичну значущість сестринсько справи та ролі медичних сестер у сучасній системі охорони здоров'я, джерела вітчизняно літератури та кра н СНД містять лише окремі праці (С. Броцька, Н. Гаврилов, Т. Ромашова, І. Шапіро, М. Шегедин), які при всій $x$ цінності висвітлюють тільки деякі аспекти зазначеного питання.

Важливою проблемою $є$ також те, що реабілітаційний процес базується на рекомендаціях із застосуванням різних засобів і методів зменшення клінічних проявів без урахування хнього взаємозв'язку. Запропоновані методи впливу нерідко мають взаємовиключаючий характер [5].

Для подальшого поновлення активно життєдіяльності пацієнта, необхідна ефективна фізична реабілітація, що сприяла б відновленню функці хребта, поліпшенню загального стану хворого.

Як відомо, медична та соціальна реабілітація включає державні, соціально-економічні, психологічні, професійні, педагогічні та інші заходи, спрямовані на запобігання захворюванням, що призводять до тимчасово і стійко втрати працездатності, та повернення хворих й інвалідів до суспільно-корисно праці. Разом 3 тим, можна констатувати недостатню розробленість теоретичних і методичних основ підготовки майбутніх медичних сестер у медичних коледжах до роботи з хворими на остеохондроз хребта.

Вивчення досвіду ціє підготовки дозволяє стверджувати, що під час навчання не забезпечується достатня підготовка до розв'язання проблемних ситуацій, які виникають при здійсненні реабілітаційних заходів щодо хворих на остеохондроз хребта. Отже, соціальне замовлення суспільства на професійного фахівця, здатного ефективно реалізувати медичну та соціальну реабілітацію, зумовлює необхідність вдосконалення якості ціє підготовки.

Метою статті є розкриття ролі медичних cecтер у реабілітаці хворих на остеохондроз хребта.

Ефективним засобом лікування $\epsilon$ не лише вдало проведене лікування, але й відновні заходи, істотними складовими яких $є$ різні форми лікувально фізично культури, водолікування, масаж, а також інші методи фізично реабілітаці , що доведено в наукових працях Т. Бойчука, 
А. Каптеліна, А. Некрасова, О. Марченко, R. Robinson та інших.

Як відомо, до професійно діяльності медично сестри належить реалізація етапів медсестринського процесу під час проведення комплексу реабілітаційних заходів, а саме: оцінювання стану пацієнта, з'ясування дійсних, потенційних, пріоритетних та супутніх проблем, складання й реалізація плану медсестринських втручань та оцінка його ефективності.

Обов'язком медично сестри $€$ не тільки проведення медсестринсько діагностики хворих на остеохондроз хребта, а й реалізація індивідуальних програм реабілітаційних заходів, ознайомлення пацієнта з правилами поведінки під час проведення фізіотерапевтичних процедур, ЛФК, масажу; надання невідкладно долікарсько допомоги в разі виникнення ускладнень під час реабілітаційних заходів; проведення санітарно-освітньо роботи з пацієнтами, х рідними та близькими; оформлення індивідуально карти пацієнта та відповідно документаці для скерування на МСEК, до відділення соціального захисту тощо [6].

До професійних вмінь медично сестри також належить складання та проведення комплексів ранково гігієнічно гімнастики та комплексів ЛФК, проведення антропометричних вимірювань й функціональних проб.

Під час проведення реабілітаційних заходів медична сестра повинна дотримуватися правил техніки безпеки, охорони праці в медичній галузі, протиепідемічного режиму та професійно безпеки.

Як зазначають Г. Юмашев та К. Ренкер, важливе значення у реабілітаційному процесі має дотримання медичною сестрою загальних правил, а саме: ранній початок, етапність, комплексність, індивідуальність, повернення до активно суспільно-корисно праці [7].

Успішність реабілітаційних заходів багато у чому залежить від дотримання медичною сестрою послідовності етапів: стаціонарного, санаторно-курортного та амбулаторно-поліклінічного, або диспансерного. Слід зауважити, що кожен етап має відповідну мету, яку медична сестра повинна чітко усвідомлювати.

\section{ЛІТЕРАТУРА}

1. Філатов А. М. Нетрадиційні методи лікування в комплексній терапії хворих літнього віку з розповсюдженим остеохондрозом хребта / А. М. Філатов, В. О. Фіщенко, А. В. Макогончук // Проблеми остеології. - 2000. - Т. 3, № 2-3. - С. 45-47.
Так, стаціонарний етап має на меті порятунок життя, попередження ускладнень.

Метою санаторно-курортного етапу $є$ профілактика рецидивів хвороби та прогресування. Для реалізаці цих завдань медична сестра має використовувати природні чинники з метою нормалізаці мікроциркуляці, підвищення кардіореспіраторних резервів, стабілізаці функцій нервово, ендокринно та імунно систем, органів шлунково-кишкового тракту та сечовиділення.

На поліклінічному етапі завершується патологічний процес, для чого вживаються відповідні заходи, спрямовані на ліквідацію залишкових явищ. Саме на цьому етапі збільшується обсяг залежних медсестринських втручань та розширюється діапазон незалежних, від якісного виконання яких залежить результат лікування в цілому.

У межах диспансерного етапу медичною сестрою створюються умови для нормалізаці структурно-метаболічних порушень, які було діагностовано на доклінічній стаді хвороби та збереглися після завершення клінічно стаді.

До арсеналу засобів реабілітаці, в реалізаці яких провідну роль відіграє медична сестра, належать: проведення медикаментозного лікування, фізіотерапі, лікувально фізкультури (кінезотерапі), різних видів масажу, кліматотерапі, психотерапі, соціально допомоги.

Висновки. Захворювання хребта посідають одне з перших місць за поширеністю серед населення земно кулі. Від адекватно спланованого та якісно проведеного реабілітаційного етапу залежить успіх лікування в цілому. Велику роль у цьому відіграють медичні сестри, підготовка яких - це цілеспрямований, послідовний, багатоетапний процес накопичення творчого потенціалу, під час якого формуються та розвиваються професійні здібності, що визначають готовність фахівця до професійно діяльності. Проблема ціє підготовки не $\epsilon$ вичерпно розкритою, тому потребує детальнішого аналізу й вирішення.

Подальші дослідження будуть спрямовані на удосконалення підготовки медичних сестер до реабілітаці хворих із дегенеративними захворюваннями хребта.

2. Кудрявцева Т. О. Специфіка підготовки майбутніх медичних сестер до розв'язання проблемних ситуацій у профресійній діяльності / Т. О. Кудрявцева / / Гуманізація навчально-виховного процесу : зб. наук. праць. Слов'янськ : Слов'янський держ. пед. ун-т, 2012. Вип. ㄴIX. - C. 51-56. 
3. Поворознюк В. В. Профрілактика та лікування остеохондрозу хребта залежно від типу старіння опорнорухового апарату / В.В.Поворознюк, В. О. Фіщенко, А. М. Філатов / / Інформаційний лист. - К., 2002. № $58 .-$ C. 3.

4. Фавваз Ф. Общие подходы к построению программ фризической реабилитации в предоперационном периоде у больных остеохондрозом позвоночника направленных на удапение грыж межпозвонковых дисков / Ф. Фавваз / / Теорія і методика фізичного виховання. - 2011. - № 4. - С. 71-74.
5. Плахтій П. Профрілактика і лікування остеохондрозу хребта / П. Плахтій, О. Галаченко, В. Пікуш. - Кам'янець-Подільський : ППБуйницький О. А. - 2011. - 112 с.

6. Реабилитология : методические указания к аудиторной работе для студентов по специальности $060109-$ сестринское дело (дневная и заочная формы обучения) / сост. Ж. Е. Турчина, Т. Р. Камаева. - Красноярск : типография КрасГМУ. - 2009. - 136 с.

7. Юмашев Г. Основы реабилитации / Г. Юмашев, К. Ренкер. - М. : Медицина. - 1973. - 112 с.

Отримано 26.02.15 